Supporting Information for

\title{
Self-priming hairpin-utilized isothermal amplification enabling ultrasensitive nucleic acid detection
}

Ja Yeon Song ", Yujin Jung", Seoyoung Lee, and Hyun Gyu Park*

Department of Chemical and Biomolecular Engineering (BK 21+ program), KAIST, Daehak-ro 291, Yuseong-gu, Daejeon 34141, Republic of Korea

ॠThese authors contributed equally to this work.

* To whom correspondence should be addressed.

E-mail: hgpark@kaist.ac.kr (H.G. Park); Phone: +82-42-350-3932; Fax: +82-42-350-3910. 
Table S1. Oligonucleotide sequences studied in this work.

\begin{tabular}{|c|c|}
\hline Name & DNA sequence $\left(5^{\prime} \rightarrow 3^{\prime}\right)^{a}$ \\
\hline Target DNA_59 & $\begin{array}{l}\text { AGG TCT AGG GTG CGC TCT GCT TCG GCT CTC TGC TGT TTC AAG TCG } \\
\text { TCC AGC TCG TTC TT }\end{array}$ \\
\hline Target DNA_30 & GTG CGC TCT GCT TCG GCT CTC TGC TGT TTC \\
\hline Target DNA_40 & GTG CGC TCT GCT TCG GCT CTC TGC TGT TTC AAG TCG TCC A \\
\hline MT1 $^{b}$ & $\begin{array}{l}\text { AGG TCT AGG GTC CGC TCT GCT TCG GCT CTC TGC TGT TTC AAG TCG TCC } \\
\text { AGC TCG TTC TT }\end{array}$ \\
\hline MT2 $^{\text {b }}$ & 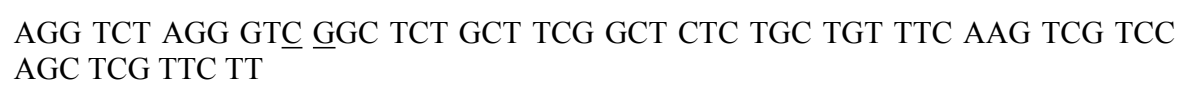 \\
\hline MT3 $^{b}$ & 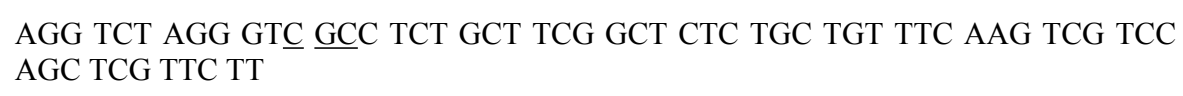 \\
\hline NC & $\begin{array}{l}\text { AGC TTT GGC GAT TTG GTC AGG CAT AAT CGC CGA CAT TCT TTC TAC ACG } \\
\text { GAT CCA AGT AT }\end{array}$ \\
\hline HP1 $1^{c, d}$ & $\begin{array}{l}\text { CCG ACC TTC CAC CGA } G C T \text { A } A \text { TC CTG GAC GAC TTG AAA CAG CAG AGA } \\
\text { GCC GAA GCA GAG CGC ACC CTG CTG } T T T C A A T C G T C C A G T T A A A\end{array}$ \\
\hline HP2 $^{\mathrm{c}}$ & $\begin{array}{l}\text { GGT GCG CTC TGC TTC GGC TTG AAA CAG CAG AGA GCC GAA GCA GAG } \\
\text { CGC ACC } A C T \text { AGA TCC CCG ACC TTC CAC CGA }\end{array}$ \\
\hline Forward primer_221 & TTG GTT TCC AAC AGG TCT AGG G \\
\hline Reverse primer_221 & CAA AGC GAG CAG AAA ATA ACC G \\
\hline Forward primer_548 & TTT CCT GCT CTA GCT CTG C \\
\hline Reverse primer_548 & AAA GGC GCA CTG TAT GAG C \\
\hline RSV RNA target & $\begin{array}{l}\text { GUG AUU CAA CAA UGA CCA AUU AUA UGA AUC AAU UAU CUG AAU UAC } \\
\text { UUG GAU UUG AUC UUA AUC CAU AAA UUA }\end{array}$ \\
\hline HP1 ${ }^{c, d}$ for RNA target & $\begin{array}{l}C C G \text { ACC TTC CAC CGA } G C T \text { A GA } T C C \text { ATG GAT TAA GAT CAA ATC CAA GTA } \\
\text { ATT CAG ATA ATT GAT TCA TTG GAT } T T G A T C T T A A C C A T A T C C A A\end{array}$ \\
\hline
\end{tabular}


HP2 $^{c}$ for RNA target

HP1 ${ }^{\text {c,d }}$ for Nb.BvbCI

HP2 $^{c}$ for Nb.BvbCI
TGA ATC AAT TAT CTG AAT GAT CAA ATC CAA GTA ATT CAG ATA ATT GAT

TCA GCT AGA TCC CCG ACC TTC CAC CGA

CCG ACC TTC CAC CGA $G C T$ GA G CT GGA CGA CTT GAA ACA GCA GAG AGC

CGA AGC AGA GCG CAC CCT GCT GTT TCA AGT CGT CCA G TT GAA A

GGT GCG CTC TGC TTC GGC TTG AAA CAG CAG AGA GCC GAA GCA GAG CGC ACC GCT GAG GCC GAC CTT CCA CCG A

\footnotetext{
${ }^{\mathrm{a}}$ The colors of oligonucleotide sequences correspond to those of the domains depicted in Scheme 1.

${ }^{\mathrm{b}}$ Underlined letters in MT indicate the mismatched bases.

${ }^{\mathrm{c}}$ Bold letters in HP represent the target DNA recognition sites.

${ }^{\mathrm{d}}$ Italic letters in HP1 represent the self-priming domain.
} 
Table S2. Comparison of the SPHIA method with previous isothermal amplification methods for target DNA detection.

\begin{tabular}{|c|c|c|c|}
\hline Method & $\begin{array}{l}\text { Detection } \\
\text { limit }\end{array}$ & Limitations & Reference \\
\hline $\begin{array}{l}\text { Nicking endonuclease } \\
\text { signal amplification }\end{array}$ & $0.1 \mathrm{fM}$ & Labeling with fluorophore & $\mathrm{S} 1$ \\
\hline $\begin{array}{l}\text { Circular strand- } \\
\text { displacement } \\
\text { polymerization } \\
\text { reaction }\end{array}$ & $6.4 \mathrm{fM}$ & $\begin{array}{l}\text { Labeling with fluorophore and } \\
\text { quencher }\end{array}$ & $\mathrm{S} 2$ \\
\hline $\begin{array}{l}\text { Strand Displacement } \\
\text { Amplification }\end{array}$ & $1 \mathrm{nM}$ & Low sensitivity & $\mathrm{S} 3$ \\
\hline $\begin{array}{l}\text { Exonuclease III-aided } \\
\text { target recycling }\end{array}$ & $10 \mathrm{pM}$ & $\begin{array}{c}\text { Labeling with fluorophore and } \\
\text { quencher } \\
\text { Low sensitivity }\end{array}$ & S4 \\
\hline $\begin{array}{l}\text { Cascade enzymatic } \\
\text { signal amplification }\end{array}$ & $1 \mathrm{fM}$ & $\begin{array}{l}\text { Labeling with fluorophore and } \\
\text { quencher } \\
\text { Exchange of reaction buffer } \\
\text { condition }\end{array}$ & S5 \\
\hline $\begin{array}{l}\text { G-quadruplex based } \\
\text { two-stage isothermal } \\
\text { amplification reaction }\end{array}$ & $2.5 \mathrm{pM}$ & $\begin{array}{l}\text { Short target DNA } \\
\text { Additional hemin incubation step }\end{array}$ & S6 \\
\hline $\begin{array}{l}\text { Self-priming hairpin- } \\
\text { utilized isothermal } \\
\text { amplification }\end{array}$ & $28.9 \mathrm{aM}$ & - & This work \\
\hline
\end{tabular}




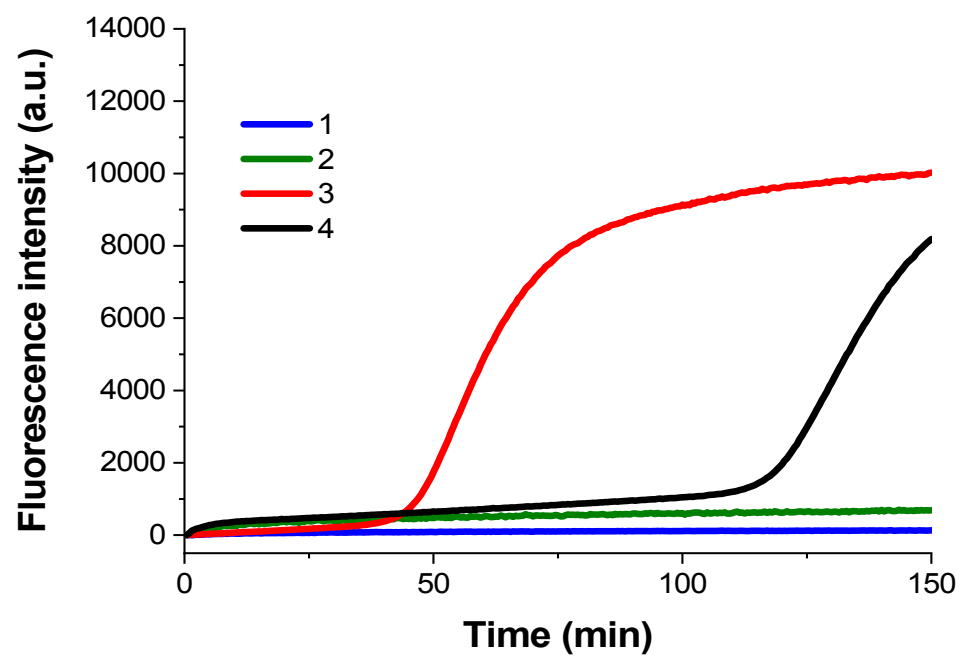

Figure S1. Feasibility of SPHIA reaction with Nb.BbvCI. (a) Real-time fluorescence curves during SPHIA reaction (1: HP1 + Target DNA + KF + Nb.BbvCI, 2: HP1 + HP2 + Target $\mathrm{DNA}+\mathrm{KF}, 3: \mathrm{HP} 1+\mathrm{HP} 2+$ Target DNA $+\mathrm{KF}+\mathrm{Nb} . \mathrm{BbvCI}$, and 4: HP1 + HP2 + KF + $\mathrm{Nb} . \mathrm{BbvCI}$ ). The final concentrations of target DNA, HP1, HP2, KF, and Nb.BbvCI are $1 \mathrm{nM}$, $25 \mathrm{nM}, 25 \mathrm{nM}, 0.125 \mathrm{U} / \mu \mathrm{L}$, and $0.5 \mathrm{U} / \mu \mathrm{L}$, respectively. 
(a)

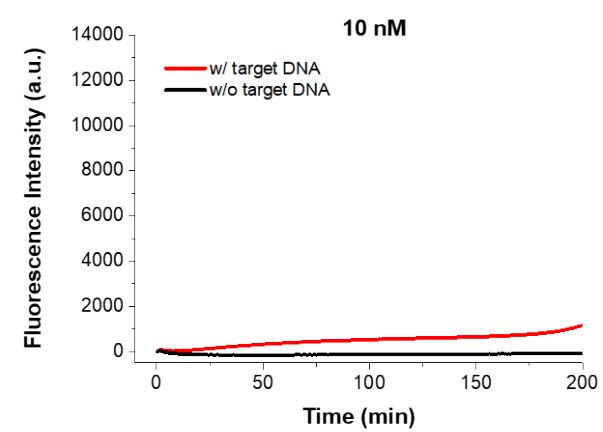

(c)

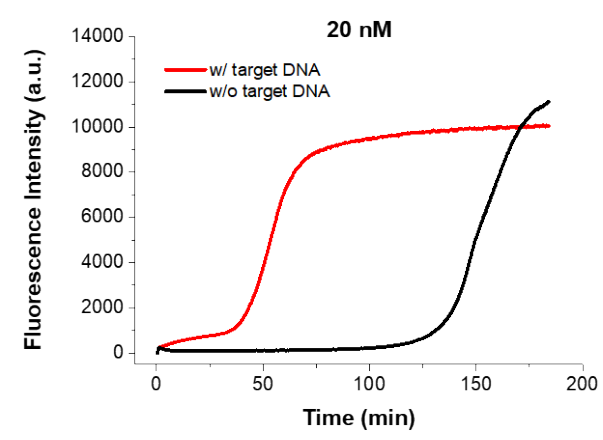

(e)

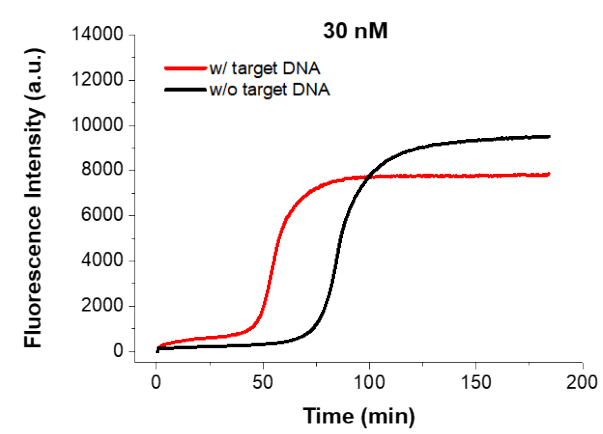

(b)

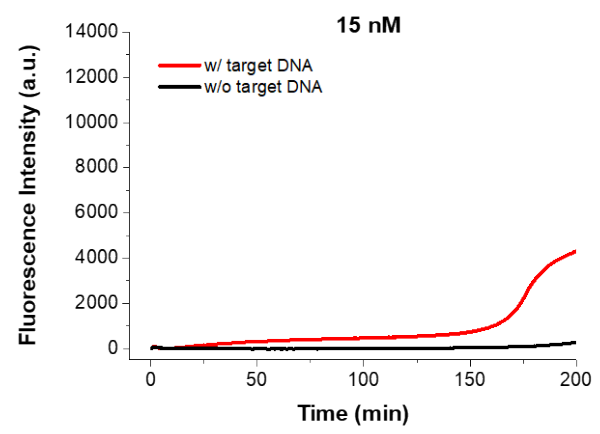

(d)

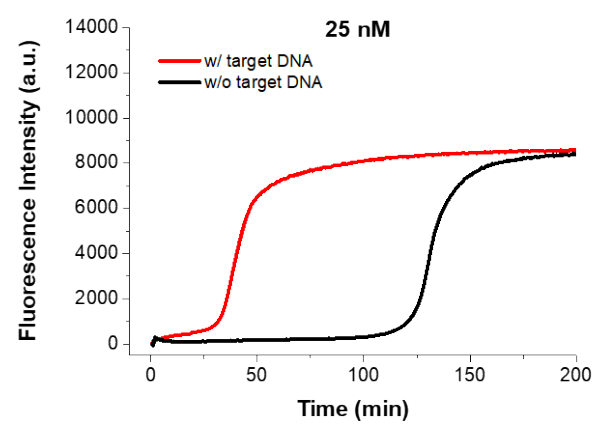

Figure S2. Optimization of the HP1 and HP2 concentrations. The real-time fluorescence curves were obtained from SPHIA reaction for the samples without target DNA (Black) and with target DNA (Red). The concentration of HP1 and HP2 are (a) $10 \mathrm{nM}$, (b) $15 \mathrm{nM}$, (c) 20 $\mathrm{nM}$, (d) $25 \mathrm{nM}$, and (e) $30 \mathrm{nM}$. The final concentrations of target DNA, KF, and Nt.AlwI are $1 \mathrm{nM}, 0.125 \mathrm{U} / \mu \mathrm{L}$, and $0.5 \mathrm{U} / \mu \mathrm{L}$, respectively. 
(a)

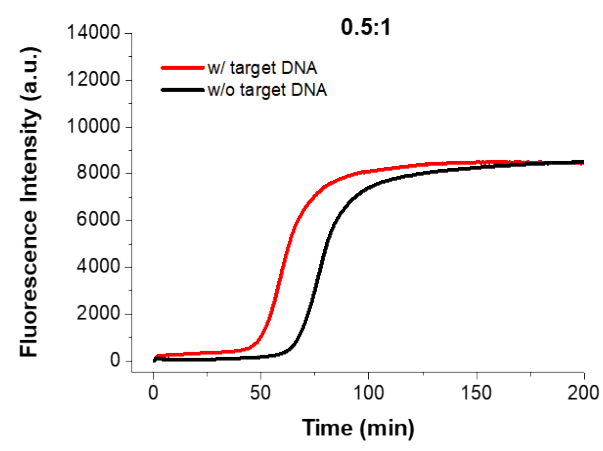

(c)

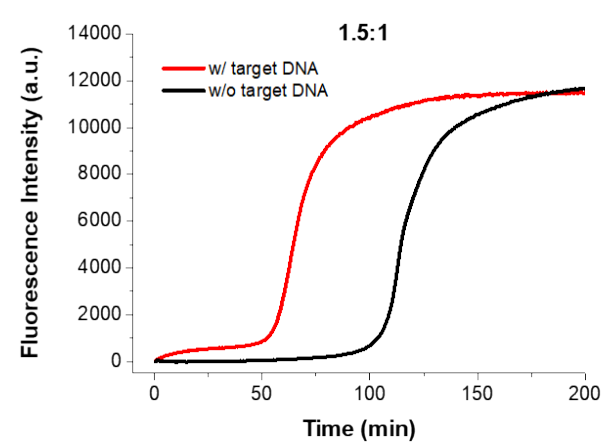

(e)

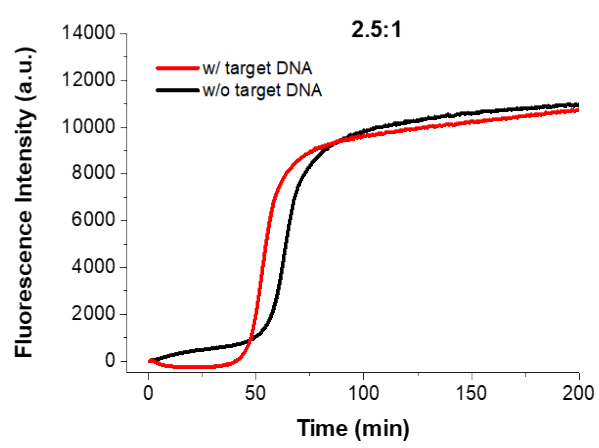

(b)

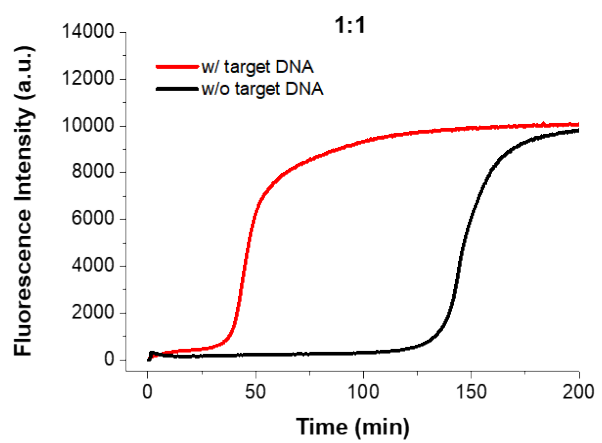

(d)

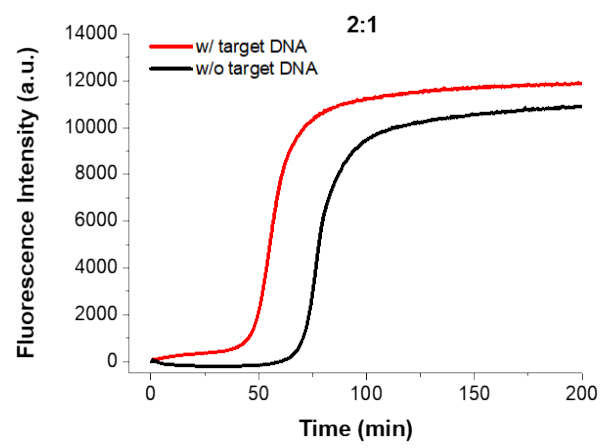

Figure S3. Optimization of the ratio of HP1 to HP2. The real-time fluorescence curves were obtained from SPHIA reaction for the samples without target DNA (Black) and with target DNA (Red). The ratio of HP1 to HP2 are (a) $0.5: 1$, (b) $1: 1$, (c) $1.5: 1$, (d) $2: 1$, and (e) $2.5: 1$. The final concentrations of target DNA, HP2, KF, and Nt.AlwI are $1 \mathrm{nM}, 25 \mathrm{nM}, 0.125 \mathrm{U} / \mu \mathrm{L}$, and $0.5 \mathrm{U} / \mu \mathrm{L}$, respectively. 
(a)

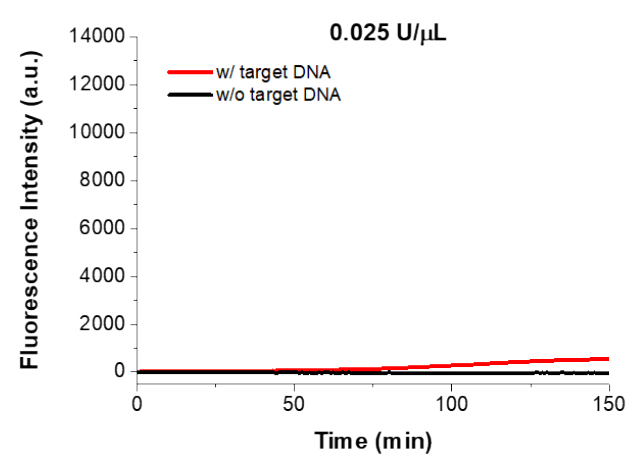

(c)

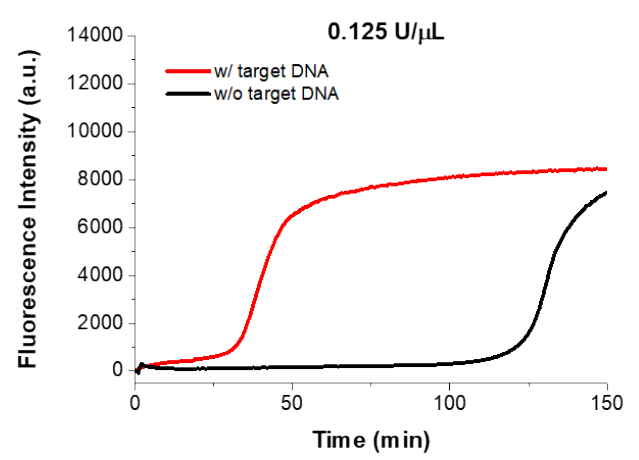

(e)

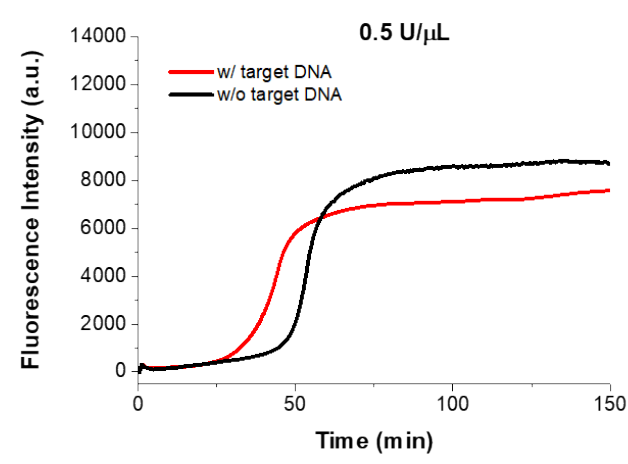

(b)

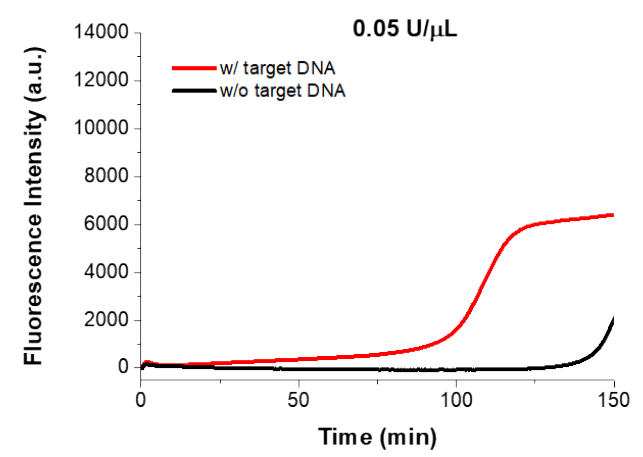

(d)

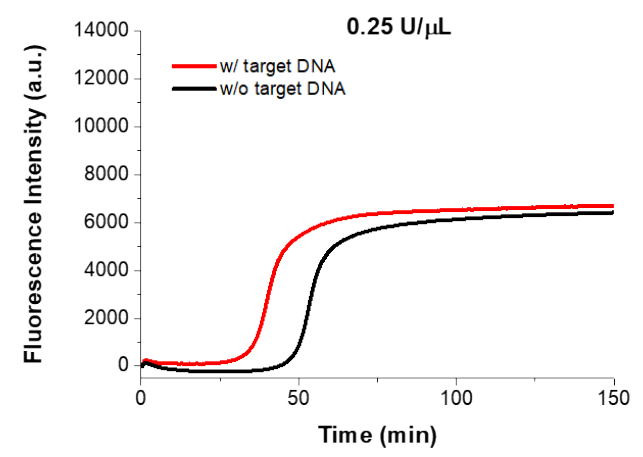

Figure S4. Optimization of Klenow fragment (3'-5' exo-) (KF) concentration. The real-time fluorescence curves were obtained from SPHIA reaction for the samples without target DNA (Black) and with target DNA (Red). The amounts of KF are (a) $0.025 \mathrm{U} / \mu \mathrm{L}$, (b) $0.05 \mathrm{U} / \mu \mathrm{L}$, (c) $0.125 \mathrm{U} / \mu \mathrm{L}$, (d) $0.25 \mathrm{U} / \mu \mathrm{L}$, and (e) $0.5 \mathrm{U} / \mu \mathrm{L}$. The final concentrations of target DNA, HP1, HP2, and Nt.AlwI are $1 \mathrm{nM}, 25 \mathrm{nM}, 25 \mathrm{nM}$, and $0.5 \mathrm{U} / \mu \mathrm{L}$, respectively. 
(a)

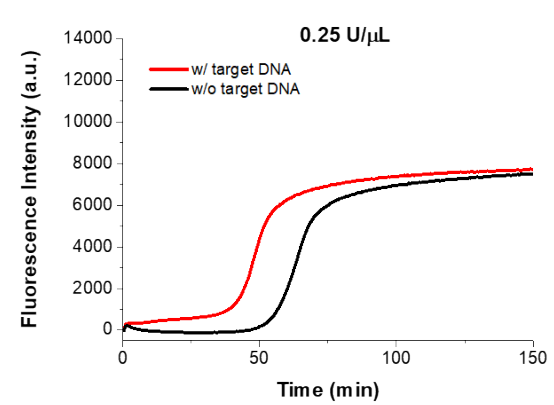

(c)

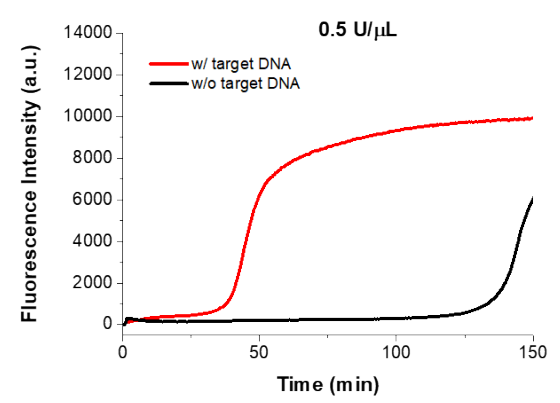

(e)

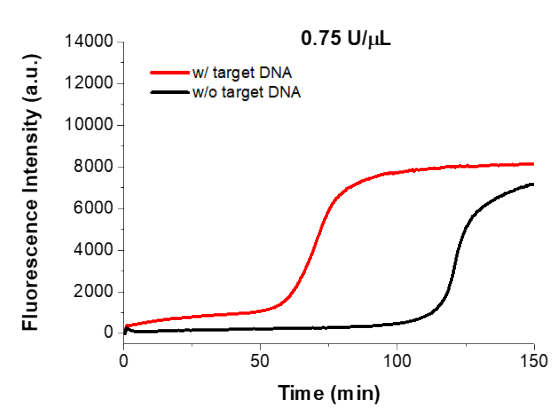

(b)

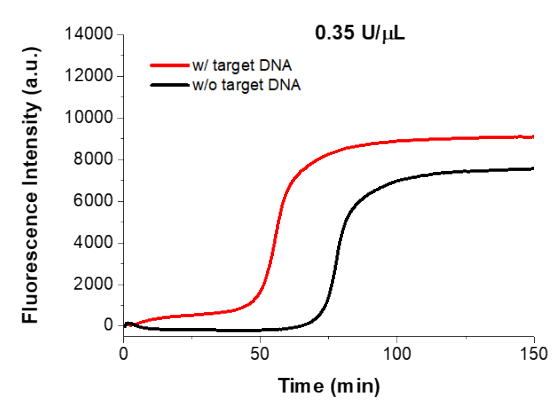

(d)

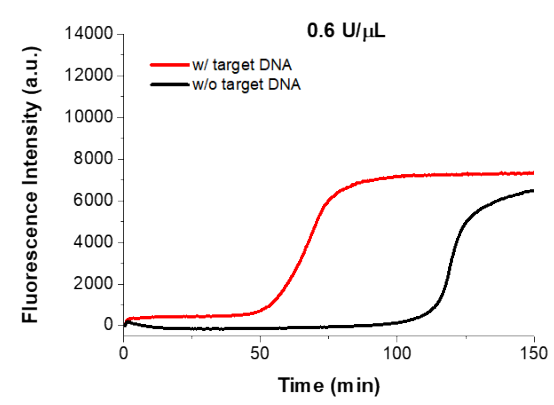

Figure S5. Optimization of Nt.AlwI nicking endonuclease concentration. The real-time fluorescence curves were obtained from SPHIA reaction for the samples without target DNA (Black) and with target DNA (Red). The concentrations of Nt.AlwI nicking endonuclease are (a) $0.25 \mathrm{U} / \mu \mathrm{L}$, (b) $0.35 \mathrm{U} / \mu \mathrm{L}$, (c) $0.5 \mathrm{U} / \mu \mathrm{L}$, (d) $0.6 \mathrm{U} / \mu \mathrm{L}$, and (e) $0.75 \mathrm{U} / \mu \mathrm{L}$. The final concentrations of target DNA, HP1, HP2, and KF are $1 \mathrm{nM}, 25 \mathrm{nM}, 25 \mathrm{nM}$, and $0.125 \mathrm{U} / \mu \mathrm{L}$, respectively. 
(a)

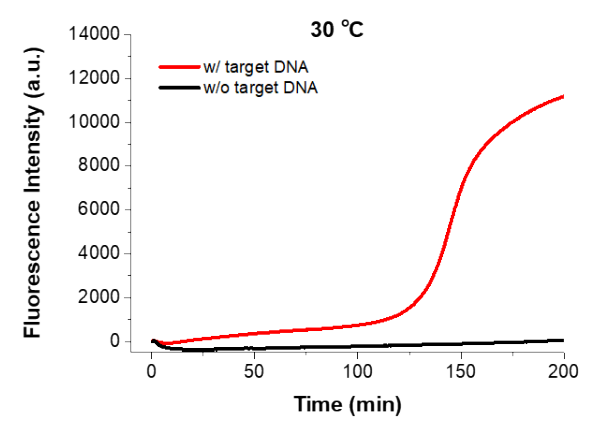

(c)

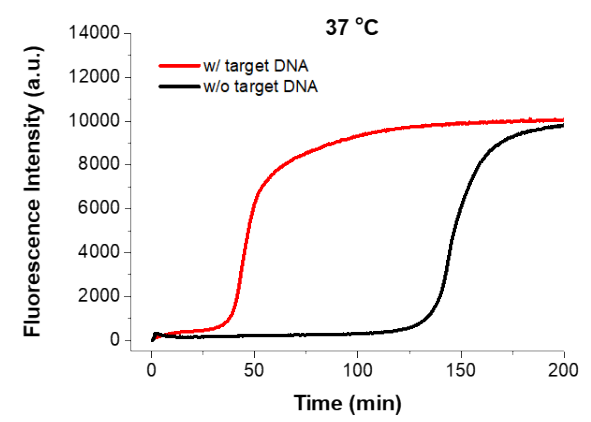

(e)

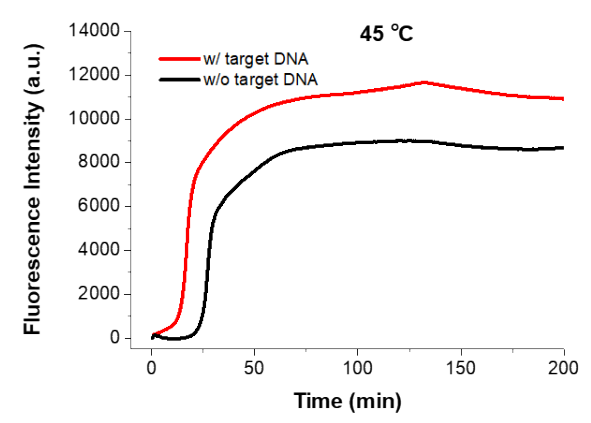

(b)

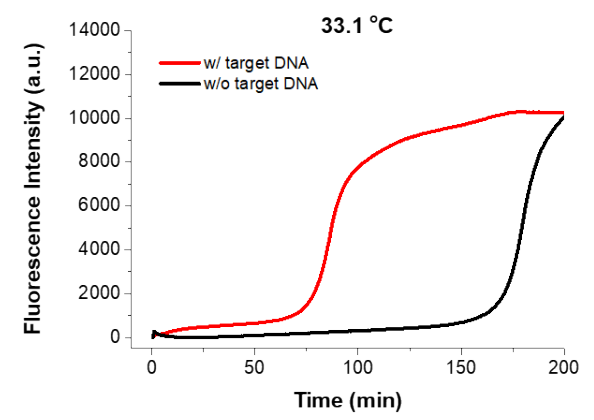

(d)

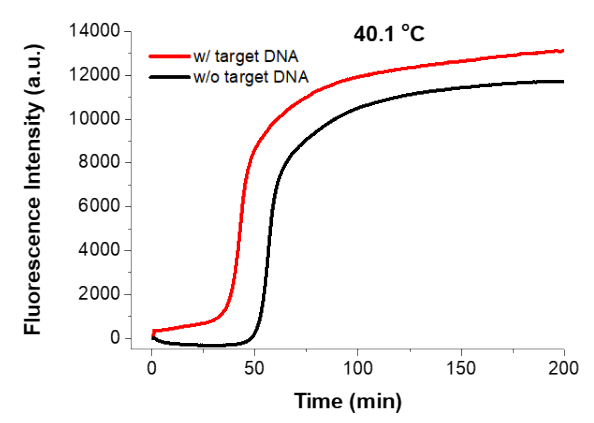

Figure S6. The effects of reaction temperature on SPHIA reaction. The real-time fluorescence curves were obtained from SPHIA reaction for samples without target DNA (Black) and with target DNA (Red) after the operation of SPHIA reaction. The reaction temperatures are (a) $30{ }^{\circ} \mathrm{C}$, (b) $33.1{ }^{\circ} \mathrm{C}$, (c) $37{ }^{\circ} \mathrm{C}$, (d) $40.1{ }^{\circ} \mathrm{C}$, and (e) $45^{\circ} \mathrm{C}$. The final concentrations of target DNA, HP1, HP2, KF, and Nt.AlwI are $1 \mathrm{nM}, 25 \mathrm{nM}, 25 \mathrm{nM}, 0.125 \mathrm{U} / \mu \mathrm{L}$, and $0.5 \mathrm{U} / \mu \mathrm{L}$, respectively. 
(a)

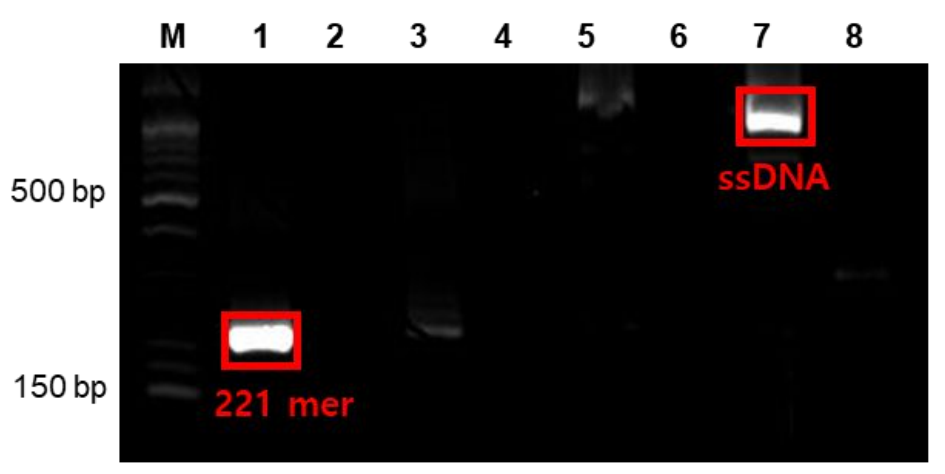

(b)

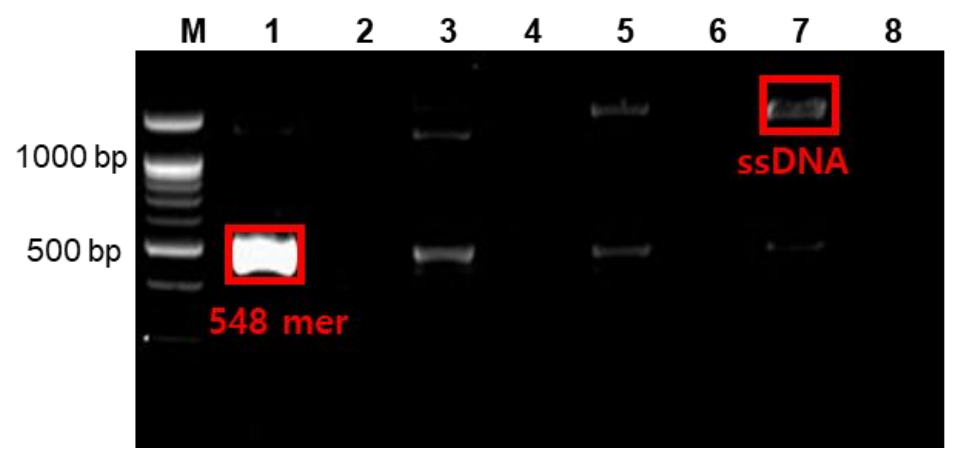

Figure S7. The agarose gel electrophoresis image of PCR products produced using various concentration ratios of forward primer to reverse primer (1 and 2: Positive and negative samples, respectively, with 1:1 primer concentration ratio, 3 and 4: Positive and negative samples, respectively, with 5:1 primer concentration ratio, 5 and 6: Positive and negative samples, respectively, with 10:1 primer concentration ratio, 7 and 8: Positive and negative samples, respectively, with 20:1 primer concentration ratio, M: Ultra low range ladder). Positive and negative samples indicate the samples obtained after PCR with and without NG plasmid DNA, respectively. (a) Forward primer_221 and reverse primer_221 were used. (b) Forward primer_548 and reverse primer_548 were used. The sequences are listed in Table S1. 


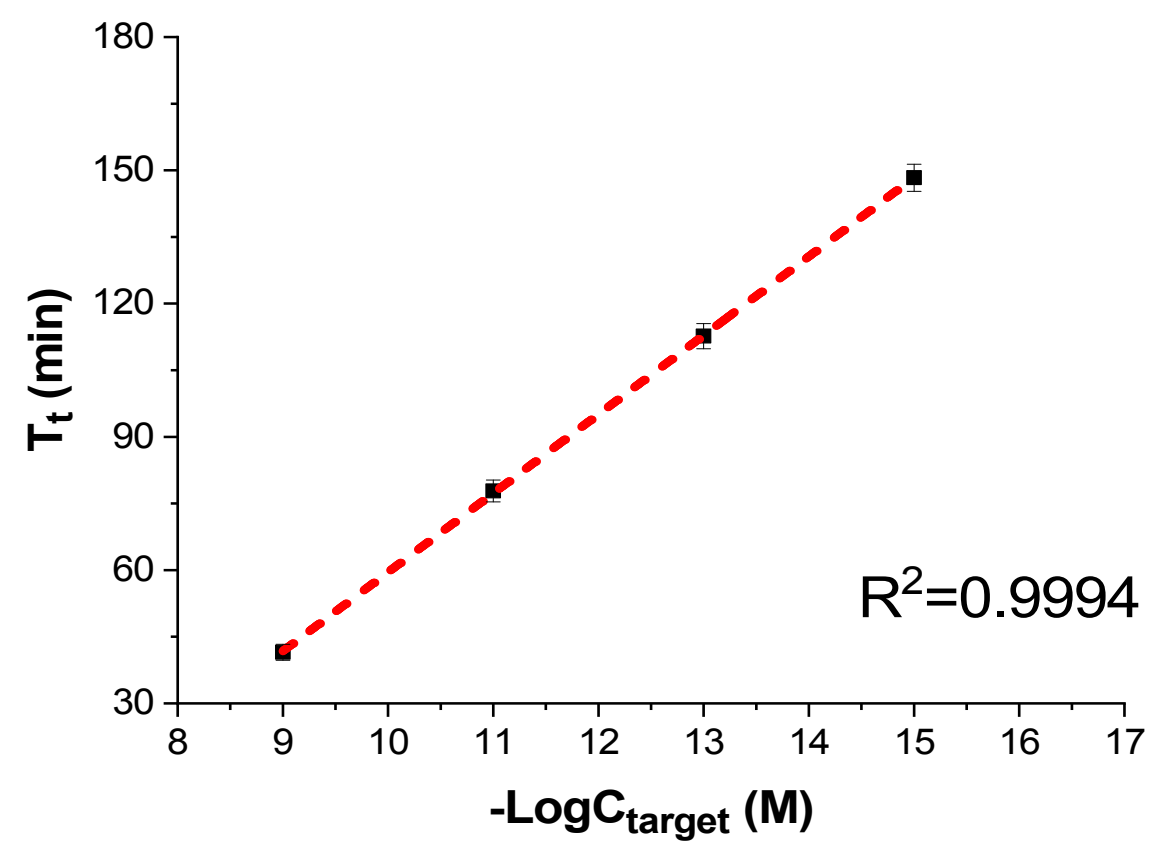

Figure S8. The correlation of threshold time to logarithm of the concentration of target DNA spiked in diluted human serum $(1 \%) . T_{t}$ was defined as the reaction time when the fluorescence intensity is over 1500 . The final concentrations of target DNA, HP1, HP2, KF, and Nt.AlwI are $1 \mathrm{nM}, 25 \mathrm{nM}, 25 \mathrm{nM}, 0.125 \mathrm{U} / \mu \mathrm{L}$, and $0.5 \mathrm{U} / \mu \mathrm{L}$, respectively. 


\section{References}

S1. $\quad$ T. Kiesling.; K. Cox.; E. A. Davidson.; K. Dretchen.; G. Grater.; S. Hibbard.; R. S. Lasken.; J. Leshin.; E. Skowronski.; M. Danielsen. Sequence specific detection of DNA using nicking endonuclease signal amplification (NESA). Nucleic Acids Res, 2007, 35, e117.

S2. $\quad$ Q. Guo.; X. Yang.; K. Wang.; W. Tan.; W. Li.; H. Tang.; H. Li. Sensitive Fluorescence Detection of Nucleic Acids Based on Isothermal Circular Strand-Displacement Polymerization Reaction. Nucleic Acids Res, 2009, 37, e20-e20.

S3. $\quad$ J.-L. He.; Z.-S. Wu.; H. Zhou.; H.-Q. Wang.; J.-H. Jiang.; G.-L. Shen.; R.-Q. Yu. Fluorescence aptameric sensor for strand displacement amplification detection of cocaine. Anal Chem, 2010, 82, 1358-1364.

S4. X. Zuo.; F. Xia.; Y. Xiao.; K. W. Plaxco. Sensitive and selective amplified fluorescence DNA detection based on exonuclease III-aided target recycling. J Am Chem Soc, 2010, 132, 18161818 .

S5. B. Zou.; Y. Ma.; H. Wu.; G. Zhou. An aptamer cross-linked hydrogel as a colorimetric platform for visual detection. Angew Chem Int Ed Engl, 2011, 50, 7395-7398.

S6. J. Nie.; D.-W. Zhang.; C. Tie.; Y.-L. Zhou.;X.-X. Zhang. G-quadruplex based two-stage isothermal exponential amplification reaction for label-free DNA colorimetric detection. Biosens Bioelectron, 2014, 56, 237-242. 